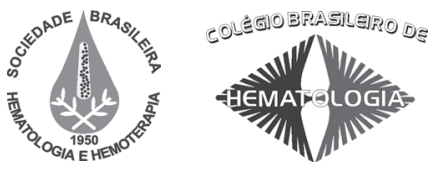

Review / Revisão

\title{
Coagulation abnormalities in acute promyelocytic leukemia
}

\section{Alterações da coagulação associadas à leucemia promielocítica aguda}

Rafael H. Jacomo

Eduardo M. Rego

\begin{abstract}
Acute promyelocytic leukemia is frequently accompanied by coagulation abnormalities usually described as laboratorial disseminated intravascular coagulation, which is the main cause of morbidity and early mortality. Aberrant activation of the coagulation cascade and hyperfibrinolysis play an important role in the pathogenesis of bleeding diathesis, but their contribution varies from case to case. Here we review the main laboratorial findings and the recommended clinical management of coagulopathy associated with acute promyelocytic leukemia. Rev. Bras. Hematol. Hemoter. 2009; 31(Supl. 2): 48-50.
\end{abstract}

Key words: Acute promyelocytic leukemia; coagulation; fibrinolysis; disseminated intravascular coagulation.

\section{Itroduction}

Acute promyelocytic leukemia (APL) is invariably associated with recurrent chromosomal abnormalities involving the receptor of retinoic acid (RAR ). In about $98 \%$ of the cases the companion gene involved is the promyelocytic leukemia gene (PML), resulting in the PML$\mathrm{RAR} \alpha$ fusion gene and a chimeric protein with reduces sensitivity to retinoic acid. Nevertheless, pharmacological doses of all-trans retinoic (ATRA) can disrupt this resistance and lead to differentiation of leukemic blasts. ${ }^{1-7}$ Consequently, protocols which associate ATRA and standard chemotherapy have become the standard in this disease and remission rates of almost $90 \%$ have been achieved. ${ }^{8,9}$

Clinically, a major aspect of APL is the presence of coagulation abnormalities and about sixty percent of patients present at least minor bleeding at diagnosis. ${ }^{10,11}$ Before the availability of ATRA, from 10 to 30 percent of patients died early during treatment. ${ }^{11-13}$ Despite the high cure rates reported, the coagulopathy is still the main factor responsible for morbidity in this disease 14 and the cause of early mortality. ${ }^{9}$

\section{Laboratorial Hemostasis in APL}

Most APL patients present at diagnosis with prolonged prothrombin time, partial thromboplastin time and thrombin time, hypofibrinogenemia, high D-Dimers and low platelet counts. ${ }^{15-18}$ The thrombin-antithrombin complex (TAT) and fibrinopeptide A are elevated, which represent intravascular thrombin formation and activation of the coagulation cascade in vivo suggesting that a mechanism similar to disseminated intravascular coagulation (DIC) may be present.

Currently, there is evidence that APL blasts express tissue factor (TF) and secrete interleukin 1, inducing activation of the coagulation cascade. ${ }^{19-21}$ Also, an alternative procoagulant, namely Cancer Procoagulant, which activates Factor X directly, is present in APL cells. ${ }^{22}$ Despite this, some peculiarities are found in APL coagulopathy: the platelet half-life is normal, ${ }^{23}$ and protein $\mathrm{C}$ and antithrombin plasmatic concentrations are normal, ${ }^{20,24}$ different from classical DIC. ${ }^{25}$ Moreover, clinical bleeding is disproportional to laboratorial data suggesting that different mechanisms may be involved.

Hematology Division, Department of Internal Medicine and Center for Cell Therapy, Medical School of Ribeirão Preto,

University of São Paulo,

Correspondence: Eduardo Magalhães Rego

Laboratório de Hematologia, Hospital das Clínicas da Faculdade de Medicina de Ribeirão Preto, Universidade de São Paulo.

Av. Bandeirantes, 3.900 - Campus USP

14048-900 - Ribeirão Preto-SP - Brasil

Tel.: (55 16) 3602-2888 - Fax.: (55 16) 3633-6695

E-mail:emrego@hcrp.fmrp.usp.br 
The detection of low levels of $\alpha 2$-antiplasmin, ${ }^{24}$ an antifibrinolytic agent, implies that an hyperfibrinolytic state may be present. ${ }^{26}$ Plasminogen activation inhibitor-1 (PAI-1) and lower levels of fibrinogen compared to DIC highlight fibrin lysis as an important mechanism in APL. ${ }^{26}$ Moreover, thrombin activated fibrinolysis inhibitor is quantitatively normal, while classically in DIC, there is consumption of this factor. ${ }^{27}$ Additionally, the promyelocytic leukemia cell line (NB4) can increase plasmin formation by 21 times in vitro. ${ }^{27}$ Another interesting point is the over-expression of annexin II in APL cells. ${ }^{28-30}$ Annexin II binds to tPA and plasminogen and improves plasmin activation by almost 200 times.

A third mechanism is involved in APL coagulopathy. The activity of some proteolytic enzymes is above normal and some of them can lyse fibrin. Elastase levels are raised, ${ }^{31}$ and there is evidence that it breaks down fibrin. As fibrin degradation products have inhibitory effects on the coagulation cascade (specially fragment D-like), this proteolysis has an anticoagulation effect.

Therefore, APL coagulopathy is peculiar. Some laboratorial data may suggest DIC, but the bleeding signs are more intense than a hemostasis test could preview. There is evidence that activation of fibrinolysis and some proteases play an important role. Hence, the coagulation abnormalities are due to at least three pathways which can explain why bleeding is so significant in this disease.

\section{ATRA effects on hemostasis}

After the introduction of ATRA in the clinical practice, an important improvement was observed in the evolution of patients. ${ }^{32-36}$ Surprisingly, besides the expected effect on cell cycle, a remarkable improvement in several coagulation tests and reduction in bleeding diathesis were observed. ${ }^{35,36}$

ATRA treatment leads to normalization in plasminogen, $\alpha 2$-plasminogen inhibitor, fibrinogen, D-dimers, TAT and fibrinopeptide A concomitantly to a reduction in TF expression. ${ }^{15,20,36}$ ATRA acts on the vascular endothelium and regulates cytokine and thrombomodulin expressions..$^{15,20}$ Curiously, there is an increase in TPA expression about 30 days after the beginning of treatment. ${ }^{36}$

\section{Patient management}

A major concern when treating APL patients is the necessity of prompt ATRA administration on suspicion. This can partially revert the coagulopathy and improve outcomes. Concomitantly, an interesting point is to avoid classical chemotherapy regimens, which can lead to worsening of bleeding. Despite a growing understanding of the pathophysiology, no specific treatment has been proposed for coagulation abnormalities. Transfusions should keep platelet counts above $30-40 \times 10^{6} / \mu \mathrm{L}$ and there is no consensus as to whether plasma and cryoprecipitate should be used prophylactically. Leukocytapheresis must be avoided due to worsening in coagulation diathesis. There is no evidence that administration of antifibrinolytic drugs has any beneficial effect.

\section{Conclusion}

APL is a standard for disease directed therapy. Survival is near $90 \%$ in some trials, but bleeding remains a major concern. Coagulation diathesis has multiple causes and can be summarized in three points: coagulation activation, fibrinolysis and proteolysis. An aggressive treatment once APL is suspected is the key to reduce morbidity and mortality.

\section{Resumo}

A leucemia promielocítica aguda (LPA) é geralmente acompanhada por anormalidades da coagulação usualmente descritas como coagulação intravascular disseminada e que são a principal causa de mortalidade precoce. A ativação anormal da cascata de coagulação e a hiperfibrinólise desempenham importante papel na patogênese da diátese hemorrágica, mas a contribuição de cada fator varia de caso a caso. Apresentamos aqui uma revisão dos principais achados laboratoriais e da recomendação para o manejo clínico da coagulopatia associada a LPA. Rev. Bras. Hematol. Hemoter. 2009;31(Supl. 2):48-50.

Palavras-chave: Leucemia promielocítica aguda; coagulação; fibrinólise; coagulação intravascular disseminada.

\section{References}

1. Rowley JD, Golomb HM, Dougherty C. 15/17 translocation, a consistent chromosomal change in acute promyelocytic leukaemia. Lancet. 1977;1(8010):549-50.

2. Larson RA, Kondo K, Vardiman JW, Butler AE, Golomb HM, Rowley JD. Evidence for a 15;17 translocation in every patient with acute promyelocytic leukemia. Am J Med. 1984;76(5):827-41.

3. Kakizuka A, Miller WH Jr, Umesono K, Warrell RP Jr, Frankel $\mathrm{SR}$, Murty VV, et al. Chromosomal translocation $\mathrm{t}(15 ; 17)$ in human acute promyelocytic leukemia fuses RAR alpha with a novel putative transcription factor, PML. Cell. 1991;66(4): $663-74$.

4. de Thé H, Lavau C, Marchio A, Chomienne C, Degos L, Dejean A. The PML-RAR alpha fusion mRNA generated by the $t(15 ; 17)$ translocation in acute promyelocytic leukemia encodes a functionally altered RAR. Cell. 1991;66(4):675-84.

5. de Thé H, Chomienne C, Lanotte M, Degos L, Dejean A. The $t(15 ; 17)$ translocation of acute promyelocytic leukaemia fuses the retinoic acid receptor alpha gene to a novel transcribed locus. Nature. 1990;347(6293):558-61.

6. Melnick A, Licht JD. Deconstructing a disease: RARalpha, its fusion partners, and their roles in the pathogenesis of acute promyelocytic leukemia. Blood. 1999;93(10):3167-215.

7. Rego EM, Pandolfi PP. Analysis of the molecular genetics of acute promyelocytic leukemia in mouse models. Semin Hematol. 2001;38(1):54-70. 
8. Huang ME, Ye YC, Chen SR, Zhao JC, Gu LJ, Cai JR, et al. Alltrans retinoic acid with or without low dose cytosine arabinoside in acute promyelocytic leukemia. Report of 6 cases. Report of 6 cases. Chin Med J (Engl). 1987;100(12):949-53.

9 Sanz MA, Martín G, González M, León A, Rayón C, Rivas C, et al. Risk-adapted treatment of acute promyelocytic leukemia with all-trans-retinoic acid and anthracycline monochemotherapy: a multicenter study by the PETHEMA group. Blood. 2004; 103(4):1237-43.

10. Jácomo RH, Melo RA, Souto FR, de Mattos ER, de Oliveira CT, Fagundes EM, et al. Clinical features and outcomes of 134 Brazilians with acute promyelocytic leukemia who received ATRA and anthracyclines. Haematologica. 2007;92(10):1431-2.

11. Tallman MS, Andersen JW, Schiffer CA, Appelbaum FR, Feusner $\mathrm{JH}$, Ogden A, et al. All-trans-retinoic acid in acute promyelocytic leukemia. N Engl J Med. 1997;337(15):1021-8.

12. Cordonnier C, Vernant JP, Brun B, Heilmann MG, Kuentz M, Bierling $\mathrm{P}$, et al. Acute promyelocytic leukemia in 57 previously untreated patients. Cancer. 1985;55(1):18-25.

13. Cunningham I, Gee TS, Reich LM, Kempin SJ, Naval AN, Clarkson BD. Acute promyelocytic leukemia: treatment results during a decade at Memorial Hospital. Blood. 1989;73(5):1116-22.

14 Steven L Soignet \& Peter G Maslak Wintrobe's Clinical Hematology. John P.Greer et al. (eds.), pp. 2191-2205 (Lippincott Williams \& Wilkins, Philadelphia, PA,2004).

15. Barbui T, Finazzi G, Falanga A. The impact of all-trans-retinoic acid on the coagulopathy of acute promyelocytic leukemia. Blood. 1998;91(9):3093-102.

16. Tallman MS, Kwaan HC. Reassessing the hemostatic disorder associated with acute promyelocytic leukemia. Blood. 1992; 79(3):543-53.

17. Bauer KA, Rosenberg RD. Thrombin generation in acute promyelocytic leukemia. Blood. 1984;64(4):791-6.

18. Myers TJ, Rickles FR, Barb C, Cronlund M. Fibrinopeptide A in acute leukemia: relationship of activation of blood coagulation to disease activity. Blood. 1981;57(3):518-25.

19. Koyama T, Hirosawa S, Kawamata N, Tohda S, Aoki N. All-trans retinoic acid upregulates thrombomodulin and downregulates tissuefactor expression in acute promyelocytic leukemia cells: distinct expression of thrombomodulin and tissue factor in human leukemic cells. Blood. 1994;84(9):3001-9.

20. Zhu J, Guo WM, Yao YY, Zhao WL, Pan L, Cai X, et al. Tissue factors on acute promyelocytic leukemia and endothelial cells are differently regulated by retinoic acid, arsenic trioxide and chemotherapeutic agents. Leukemia. 1999;13(7):1062-70.

21. Cozzolino F, Torcia M, Miliani A, Carossino AM, Giordani R, Cinotti S, et al. Potential role of interleukin-1 as the trigger for diffuse intravascular coagulation in acute nonlymphoblastic leukemia. Am J Med. 1988;84(2):240-50.

22. Falanga A, Alessio MG, Donati MB, Barbui T. A new procoagulant in acute leukemia. Blood. 1988;71(4):870-5.

23. Bennett M, Parker AC, Ludlam CA. Platelet and fibrinogen survival in acute promyelocytic leukaemia. Br Med J. 1976;2(6035):565.

24. Sakata Y, Murakami T, Noro A, Mori K, Matsuda M. The specific activity of plasminogen activator inhibitor-1 in disseminated intravascular coagulation with acute promyelocytic leukemia. Blood. 1991;77(9):1949-57.

25. Bauer KA, Kass BL, Beeler DL, Rosenberg RD. Detection of protein $\mathrm{C}$ activation in humans. J Clin Invest. 1984;74(6):2033-41.

26. Aoki N, Moroi M, Matsuda M, Tachiya K. The behavior of alpha2plasmin inhibitor in fibrinolytic states. J Clin Invest. 1977; $60(2): 361-9$.
27. Meijers JC, Oudijk EJ, Mosnier LO, Bos R, Bouma BN, Nieuwenhuis $\mathrm{HK}$, et al. Reduced activity of TAFI (thrombin-activatable fibrinolysis inhibitor) in acute promyelocytic leukaemia. Br J Haematol. 2000;108(3):518-23.

28. Menell JS, Cesarman GM, Jacovina AT, McLaughlin MA, Lev EA, Hajjar KA. Annexin II and bleeding in acute promyelocytic leukemia. N Engl J Med. 1999;340(13):994-1004.

29. Zhang X, Zhou H, Wang J, Yang L, Hu Y, Shen G, et al. Arsenic trioxide, retinoic acid and Ara-c regulated the expression of annexin II on the surface of APL cells, a novel co-receptor for plasminogen/ tissue plasminogen activator. Thromb Res. 2002;106(1):63-70.

30. Olwill SA, McGlynn H, Gilmore WS, Alexander HD. Annexin II cell surface and mRNA expression in human acute myeloid leukaemia cell lines. Thromb Res. 2005;115(1-2):109-14.

31. Sterrenberg L, Haak HL, Brommer EJ, Nieuwenhuizen W. Evidence of fibrinogen breakdown by leukocyte enzymes in a patient with acute promyelocytic leukemia. Haemostasis. 1985;15(2):126-33.

32. Di Bona E, Avvisati G, Castaman G, Luce Vegna M, De Sanctis V, Rodeghiero F, et al. Early haemorrhagic morbidity and mortality during remission induction with or without all-trans retinoic acid in acute promyelocytic leukaemia. Br J Haematol. 2000; 108(4): 689-95.

33. Sanz MA, Martín G, Rayón C, Esteve J, González M, Díaz-Mediavilla $\mathrm{J}$, et al. A modified AIDA protocol with anthracycline-based consolidation results in high antileukemic efficacy and reduced toxicity in newly diagnosed PML/RARalpha-positive acute promyelocytic leukemia. PETHEMA group. Blood. 1999; 94 (9):3015-21.

34. Sanz MA, Vellenga E, Rayón C, Díaz-Mediavilla J, Rivas C, Amutio $\mathrm{E}$, et al. All-trans retinoic acid and anthracycline monochemotherapy for the treatment of elderly patients with acute promyelocytic leukemia. Blood. 2004;104(12):3490-3.

35. Tallman MS, Lefèbvre P, Baine RM, Shoji M, Cohen I, Green D, et al. Effects of all-trans retinoic acid or chemotherapy on the molecular regulation of systemic blood coagulation and fibrinolysis in patients with acute promyelocytic leukemia. J Thromb Haemost. 2004;2(8):1341-50.

36. Barbui T, Finazzi G, Falanga A. The impact of all-trans-retinoic acid on the coagulopathy of acute promyelocytic leukemia. Blood. 1998;91(9):3093-102.

O tema apresentado foi proposto pela Organização do $8^{\circ}$ Simpósio da Associação Ítalo-Brasileira de Hematologia, realizado durante o XIII Congresso de Transplante de Medula Óssea.

Publicado após concordância do editor.

Conflito de interesse: sem conflito de interesse

Recebido: 07/07/2009

Aceito: 16/07/2009 